\title{
AGOA: Economic and Political Effects on FDI Flows Into Sub-Saharan Africa
}

\author{
Osei Yeboah \\ North Carolina Agricultural and Technical State University \\ Saleem Shaik \\ USDA-Economic Research Service \\ Michael Wuaku \\ North Carolina Agricultural and Technical State University
}

Foreign Direct Investment (FDI) is widely considered as an important stimulus to the economic growth in the form of employment, technology transfer; and regional economic integration among others. This paper seeks to determine the effects of the Africa Growth and Opportunity Act (AGOA) on FDI flows into SubSaharan Africa. Using a modified gravity model, results suggests that per capita GDP and AGOA participation status positively influences FDI inflow into Sub-Saharan Africa while being a member of other RTAs (Other Regional Trade Agreements) hinder FDI net flow. Also, countries with generally better political stability index score have higher average FDI net flow.

Keywords: foreign direct investment, AGOA, modified gravity model, Heckman selection model

\section{INTRODUCTION}

Economists generally agree that open economies develop at a faster rate than closed ones (Grossman \& Helpman, 1991; Edwards, 1993). If economic openness is truly positively related to development, then it follows that trade liberalization is a requirement for growth. International trade expansion can generate economic growth by facilitating the dissemination of knowledge and technology from the direct import of high-tech goods.

Trade is a critical factor to long-term, sustainable economic development of a country. In the 1970s, African countries were indecisive when it came to free trade. But all of this changed when countries started developing interest in multilateral trade agreements in the 1980s. This interest emanated from some African countries wanting to liberalize trade; with the belief that if trade was well managed, it will play an important role in solving the developmental challenges faced by the continent; and finally, the characteristic of trade initiating and fostering regional integration efforts (Ahmed, et.al., 2008) and even more importantly to attract foreign direct investments (FDIs) into their countries to facilitate economic growth and development.

The African Growth and Opportunities Act (AGOA) is a non-reciprocal US trade preference program, signed into law on 18th May 2000 as Title one of the Trade Development Act 2000, aimed at "increasing 
U.S. trade and investment with the region, promote sustainable economic growth through trade, and encourage the rule of law and market-oriented reforms". AGOA provides eligible sub-Saharan African countries with duty-free access to the U.S. market for over 1,800 products, in addition to the more than 5,000 products that are eligible for duty-free access under the Generalized System of Preferences (GSP) program.

As one of the key intentions of AGOA, FDIs have been found to be beneficial to both the host countries and foreign entities such as multinational corporations (MNCs) seeking to invest. For host countries, FDIs offers increase in productivity, technology transfer, managerial skills, know-how, international production networks, external market access and reduction of unemployment, (Denisia, 2010). Whereas through FDIs, multinational corporations, gain access to markets, site-specific natural resources, low-cost manpower, and opportunities to exploit the advantages of bilateral and multilateral trade policies. (Asongu, et.al., 2018).

The overall goal of this paper is to identify the economic and political factors that have driven foreign direct investments flows into Sub-Saharan Africa since the inception of AGOA. Probit and Heckman Selection models are employed to first, determine only the positive FDI flows, and then, a modified gravity equation to determine the effects of the economic and political factors on these FDIs.

The rest of the paper is structured as follows: Section 2.0 provides the literature review on FDI, AGOA and gravity model, while section 3.0 discusses the theoretical and empirical framework; Section 4.0 presents the data sources, construction, and estimation procedures while the results and discussions are presented in section 5.0; and section 6.0, the summary and conclusion of the study.

\section{LITERATURE REVIEW}

\section{Foreign Direct Investment (FDI)}

The trade and investment regime of any country is of crucial importance to business owners and investors. Stimulation of regional economic integration, market expansion, business, and investment opportunity generation. Moreover, trade and investment tend to be inherently interlinked (OECD, 2005). Open trade policy enhances greater trade by making a country more attractive to investment flows. Likewise, open investment policy attracts Foreign Direct Investment inflows, thus, increasing the likelihood of trade in the long run. Foreign Direct Investment is an investment made to acquire lasting interest in enterprises operating outside of the economy of the investor (OECD, 2008). Foreign Direct Investment (FDI) has been viewed as a major stimulus to economic growth in developing countries. (Owusu-Antwi, 2012), analyzed the various potential determinants of FDIs for African economies. The study further identified constraints that have hindered the FDI flow to Africa. The author argued that, given the importance of FDI to the African economy, there was the need for the African countries to attract greater volumes of FDI.

(Marandu, et.al., 2018) investigated trends in FDI inflows to Africa with the ultimate aim of suggesting implications for policy action using a quantitative desktop approach. The results of their findings showed that, although Africa was in an alarming need for FDI due to lack of capital investment, it was very difficult for Africa to attract as much FDI compared to developed countries and even other developing regions. The study concluded that larger portions of FDI inflows to Africa were mostly concentrated in the primary sectors of the economies. As such, benefits that were to be realized in the region were not as significant as experienced in other regions like Asia where the manufacturing sector receives larger portions of FDI inflows.

(Denisia, 2010) conducted a study on the overview of FDI theories. The main motive of the study was to identify the main trends in FDI theory and highlight how these theories were developed, the reasons that brought about the need for new approaches to enrich economic theory of FDI. The study revealed that, economic mechanisms and behavior of agents were better understood through theoretical studies on FDI's, both at micro and macro levels allowing the discovery of new areas of study in economic theory.

Journal of Applied Business and Economics Vol. 23(5) 2021259 


\section{African Growth and Opportunity Act (AGOA)}

(Ahmed, et.al., 2008), stated that, many African countries in an attempt to promote international trade in the late 1990s adopted market liberalization. This initiative opened up their economies not only to international trade but also to foreign direct investments. One of the ways that Africa has achieved market liberalization over the years is through regional trade agreements such as Africa Growth and Opportunity Act (AGOA).

(Condon \& Stern, 2011) employed a systematic review procedure and technique to evaluate the effectiveness of AGOA at increasing trade from Least Developed Countries (LDCs) and the expected impact of extending full duty-free quota-free (DFQF) access to the US market to all LDCs. The findings were that AGOA has a positive impact on clothing exports from a slight number of Sub-Saharan African LDCs and no evidence of AGOA persuaded advantages in any other sectors for LDCs. It concluded that Sub-Saharan African LDCs would rather gain under the full DFQF access to the US market because it will remove duties on products not covered by AGOA preferences, especially on agricultural supplies.

(Zenebe, et.al., 2013) also suggested that the AGOA trade preferences do not have a significant impact on Sub-Saharan Africa (SSA) agricultural exports. However, (Didia, et.al., 2015) argued that AGOA status has a strong positive and significant impact on overall trade with the US. (Carre re, 2006) a gravity model in a country pair analysis to assess the effects of export regional trade agreements. Results covering seven Regional Trade Agreements (RTAs), showed that most of these RTAs resulted in an increase in intraregional trade beyond levels predicted by the gravity model, often coupled with a reduction in imports from the rest of the world.

\section{Gravity Model}

(Xia, Houston, Escalante and Epperson, 2012) developed a trade framework that measures the impacts of transportation costs on international oilseeds trade using a gravity model. Results from the analysis revealed a relationship between income, trade flows, and trade costs through a reduced-form gravity specification. The authors explained that distance between two countries and border trade barriers have significant and practical impacts on the trade value of oilseeds and oilseeds oils because an increase in geographical distance by $1 \%$ led to a decrease in the volume of trade in oilseeds by $0.9 \%$. (Wang and Badman, 2016) probed into Peru's foreign trade by using a gravity model to identify the main economic factors that should be further enhanced to increase the value of exports. The results of their study suggested that the size of the economy has a positive and significant effect on trade, while distance has a negative effect.

(Pluper, et.al., 2006) conducted a research on the application for European Union (EU) membership by governments of transition countries in Eastern Europe using a Heckman selection model. The data supported the argument that uncontested reforms signaled the policy support of relevant political parties to the European Union and increased the likelihood of joining the union. They also tested for specification errors and checked the robustness of the findings.

\section{THEORETICAL MODEL}

The model employed to solving the overall objective of the paper is of two-stage. First, a Probit equation consisting of per capita GDP, official Exchange Rate of the host country's currency to the U.S. dollar, Index of Political Stability; and dummy variables including Language, Income Classification; and Regional Classification of the SSA sub region are used as explanatory variables to predict positive and negative FDIs. A Heckman Selection model is later employed to select only the positive FDIs, and applied to the gravity equation, which has an FDI expressed as a function of traditional trade variables including again, per capita GDP and official exchange rate; AGOA Status, and other RTAs.

\section{Heckman Selection Model and Probit}

Heckman Selection model (Heckman, 1979), has been often used in micro econometric research. Generally, a few numbers of gravity model studies have used the selection model to deal with zero flows. 
For instance, (Bikker, 1982) and (Bikker \& De Vos, 1992) made extensive use of a selection model and (Rose, 2000) estimated a variant of the Heckman Selection model in a robustness section of the paper, without interpreting the model. (Hillberry, 2002) estimated a more confined variant, in which an autonomous selection and truncated regression equation are estimated (Cragg, 1971). The Heckman Selection model is applied to correct selection bias problems and non-randomly selected samples in estimating behavioral relationship. This study makes use of the model because, the data set has some zero or missing FDIs. We assume that the missing observations in principle indicate that investment made by investors in previous years were channeled out of the various countries for unknown reasons. The Heckman equation can be expressed as

$F D I=\left\{\begin{array}{l}0, \text { if } F D I<0 \\ 1, \text { if } F D I \geq 0\end{array}\right.$

where FDI is the discrete choice between 0 and 1; and estimated using Probit model.

$p_{i}\left(x_{i}=1 \mid v_{i}\right)=F(v \beta)$

where:

$p_{i}=$ probability of Sub-Saharan African countries being able to attract FDI inflow or not

$x_{i}=1$; Sub-Saharan African countries being able to attract FDI inflow

$x_{i}=0$; Sub-Saharan African countries being able to attract FDI inflow

$F$ represents logistic cumulative distribution function

$v_{i}$ represents matrix of individual explanatory variables; and

$\beta$ represents coefficient of the variables.

\section{The Gravity Model}

The basic gravity equation concept was derived from Newton's gravity equation in physics and often used in regional science for outlining and analyzing spatial flows and was pioneered in the analysis of international trade (Tinbergen, 1962). Newton's law of gravity states that two objects attract each other with a force that is positively dependent on the product of their masses and negatively on their distance (Esmaeili \& Pourebrahim, 2011). Newton's gravity model is generally expressed as follows:

$G F_{i j}=\frac{M_{i} M_{j}}{D_{i j}}, i \neq j$

where, $G F_{i j}$ is Newton's law of gravity between two objects $i$ and $x . M_{i}$ and $M_{j}$ are the masses of the objects $i$ and $j$ and $D_{i j}$ is the distance between the two objects ( $i$ and $j$ ). In equation (3), the force of gravity is directly proportional to the masses of the object and indirectly proportional to the distance between them. Instead of the masses, the host country's GDP and population endowment are used as in equation (4).

$F D I_{i j}=\frac{G D P_{i} P O P_{j}}{D_{i j}}$

where, $F D I_{i j}$ is the value of investment flow from country $i$ to country $j, G D P_{i}$ represents the gross domestic products of country $i$ and $P O P_{j}$ represents the population of country $j, D_{i j}$ represents the geographical distance separating the ports of the two countries, $i$ and $j$.

\section{The Empirical Model}

The Heckman Selection model employed in equation (1) to predict FDI inflow can be expressed as presented in equation (5) and (6): 
$p_{i}=1-p r\left(x_{i}=1 \mid v_{i}\right)$ if $x_{i}=0$

$p_{i=} \operatorname{pr}\left(x_{i}=1 \mid v_{i}\right)$ if $x_{i}=1$

The outcome from equation (6) is then used as the dependent variable in the gravity equation as in equation (7). The basic gravity model as represented in equation (4) states that the value of investment flows is directly related to the size of the economies (GDP) and inversely related to the distance between the two trading countries $i$ and $j$. The model is estimated in natural logarithm (ln) form as:

$\ln \left(F D I_{i j}\right)=\propto_{0}+\propto_{1} \ln \left(G D P_{i j}\right)+\propto_{2} \ln \left(D_{i j}\right)$

where;

$\ln =$ Natural logarithm

$F D I_{i j}=$ Foreign Direct Investment from parent country $(i)$ to host countries $(j)$

$G D P_{i j}=$ Gross Domestic Product from parent country $(i)$ and host countries $(j)$

$D_{i j}=$ Distance between parent country $(i)$ and host countries $(j)$

For the purposes of this study, the model was modified to incorporate additional explanatory variables other than the traditional trade variables. These include language, AGOA status, RTAs, Index of Political Stability, and others already stated. Giving the lack of information with respect to country- to- country FDI investment flows, the direct investment equity flows to the countries in the Sub-Saharan region was considered. Also, due to lack of information on the origin or source of FDI, distance variable was dropped. The final modified gravity equation is expressed in equation (8):

$$
\begin{aligned}
& \ln F D I_{j t}=\propto_{0}+\propto_{1} \ln \frac{G D P}{c}_{j t}+\propto_{2} \ln E X R_{j t}+\propto_{3} \ln P S I_{j t}+\propto_{4} L A N G_{j t}+\propto_{5} A G O A_{j t}+ \\
& \propto_{6} R C_{j t}+\propto_{7} I C_{j t}+\propto_{8}{ }_{\text {ORTA }}+\varepsilon_{j t}
\end{aligned}
$$

where;

$$
\mathrm{t}=\text { Year }
$$

$G D P / c=$ Per capita GDP of the host countries

$E X R=$ Official exchange rate of the host country's currency (local currency unit) per the US dollar

$P S I=$ Political stability index

$L A N G=$ Various languages spoken by the host countries

$A G O A=$ AGOA participating Status

$R C=$ Regional Classification of countries in Sub-Saharan Africa

$I C=$ Income Classification

ORTA $=$ Other Regional Trade Agreements

$\varepsilon=$ Error term

\section{DATA SOURCE AND CONSTRUCTION}

The data source from the World Bank (2002 - 2018) supplies information on values of FDIs in millions of dollars, GDP in billions of dollars, exchange rates of the host country's currency relative to the U.S. dollar, and political stability for 39 Sub-Saharan African countries.

Data on official languages for these countries was obtained from the Internet World Statistics platform (https://www.internetworldstats.com/languages.html). Language was constructed as a dummy variable with 0 indicating French; 1, for English; and 2, for Portuguese. 
Data on AGOA participating countries was collected from the AGOA website (https://agoa.info/profiles.html) and constructed as a dummy variable with 0 indicating a non- participant in AGOA or not eligible at a particular year; and 1, Otherwise.

Data on other RTAs was obtained from the World Trade Organization (WTO) and was also constructed as a dummy variable with 0 indicating a non-member country of RTA outside AGOA at a particular time; and 1, otherwise. Regional classification data was constructed from author's computation based on data from World Bank's website.

Data on income classification was collected from https://unstats.un.org/unsd/mi/africa.htm and was constructed according to the World Bank's income group classifications standard.

\section{Estimation Procedures}

Both the Probit and the Heckman Selection models were estimated using the R Statistical package. The output from both the estimated Probit and the Heckman Selected models was fed into the gravity equation and estimated and estimated, again, using the R. The RE model was considered since it takes into account all the time-invariant variables including language, income classification, and regional classification. It also assumes that the variation across countries is random and uncorrelated with the explanatory variables in the model. That is, the error term is not correlated with any of the explanatory variables which allows the timeinvariant variables to play the role of explanatory variables.

\section{RESULTS AND DISCUSSIONS}

As expected, average FDI was highest in South sub region at $\$ 918$ million, followed by West and East Africa at $\$ 684$ million and $\$ 576$ million, respectfully while Central Africa recorded the least with $\$ 418$ million. With regards to per capita GDP, South sub region again was on top with $\$ 2,900.00$, which was almost three times that of West Africa of $\$ 1,000$. 00. Central Africa came second with $\$ 2,000.00$, and East Africa had $\$ 300$ less $(\$ 1,700.00)$. South sub region was the most politically stable region with an average political stability index of 51, almost double that of Central Africa which had the least political stability index of 26. West Africa was the second most politically stable region with an index of 33, just a point ahead of East Africa with 32.

Table 2 presents the results of the estimated Probit model. Results suggest a country's efforts in attracting FDI decreases as per capita GDP rises. The marginal effect of per capita GDP is significant $(\mathrm{p}<0.000)$. This implies that as countries' economic output increases, there is less desire to implement policies including tax breaks that would attract investors This result is consistent with (Bekana, 2016), that per capita GDP is the primary determinant of FDIs. It is also consistent with (Ahmed, et.al., 2008) stated that many African countries, in an attempt to promote international trade in the late 1990s, adopted market liberalizations. This initiative opened up their economies not only to international trade but also to foreign direct investments. Official exchange rate had a negative effect on FDI net flow. As a country's official exchange rate depreciates relative to the US dollar, the probability of its ability to attracting FDI decreases. This is consistent with a (Nyarko, et.al., 2011) study on the effects of exchange rate regimes on Ghana's FDI. The study concludes that exchange rate regime had no noticeable effect on Ghana's FDI inflow. They further argued that the link was weak at best since it was only significant at $10 \%$ level. Also, the probability of a country attracting FDI is almost zero with a decreasing political stability index. Countries that make up East African sub region have a probability of $4.7 \%$ higher to attract FDI inflow as compared to countries in the other sub regions. Results also show that countries that are either in lower or upper middle-income classification have a probability of $8.4 \%$ higher to attract FDI inflow relative to others.

Table 3 presents results of the estimated gravity equation. The coefficient for per capita GDP of 0.405 and significant at $1 \%$. This implies that a $1 \%$ rise in per capita GDP will cause FDI net flow to increase by about $0.5 \%$. This is consistent with theory since per capita GDP is an indicator of a country's purchasing power. Investors are more likely to invest in economies with high per capita GDP as the citizens are able to purchase the goods and service being produced or rendered in the FDI host country. AGOA participation 
was also significant at $1 \%$ with expected sign. SSA countries that participate in AGOA are more likely to grow their FDI net flow by $9.7 \%$ as compared to their non-participants counterparts.

\section{SUMMARY AND CONCLUSION}

The primary goal of this paper was to examine the effects of AGOA, Economic and Political environment on FDI inflow. A Probit and Heckman selection model; and modified gravity model were applied to a panel data from 2002 to 2018 for 39 Sub-Saharan African countries. To ascertain the real effects of the factors of AGOA participation, Economy, and Political stability on FDIs flowing into the sub region, only the positive FDIs were selected using Heckman selection model, and the resulting output applied to a gravity equation.

The study showed that per capita GDP has a positive effect on FDI inflow among Sub-Saharan African countries. Also, AGOA status of a country positively influences the growth of FDI while being a member of other-RTAs hinders FDI net flow. Furthermore, FDI net flow was higher in sub regions with higher economic and political stability indexes.

\section{REFERENCES}

Ahmed, A.D., Cheng, E., \& Messinis, G. (2008). The role of exports, FDI and imports in development: New evidence from sub-Saharan African countries. Working Paper No. 39. Center for Strategic Economic Studies, Victoria University, Melbourne.

Aku, H.O. (2017). The Role of Trade Agreements (Within and Outside TPP) on US Trade of Aggregate Commodities (Doctoral dissertation). North Carolina Agricultural and Technical State University.

Akuffo, A.S. (2012). The Effect of Trade Openness on Economic Growth: The Case of African Countries.

Anderson, J.E. (1979). A theoretical foundation for the gravity equation. The American Economic Review, 69(1), 106-116.

Asongu, S., Akpan, U.S., \& Isihak, S.R. (2018). Determinants of foreign direct investment in fastgrowing economies: Evidence from the BRICS and MINT countries. Financial Innovation, 4(1), 26.

Bekana, D.M. (2016). Determinants of foreign direct investment in Ethiopia; Time series evidence from 1991-2013. The Journal of Developing Areas, 50(1), 141-155.

Bergstrand, J.H. (1985). The gravity equation in international trade: Some microeconomic foundations and empirical evidence. The Review of Economics and Statistics, pp. 474-481.

Bikker, J.A., \& De Vos, A.F. (1992). An international trade flow model with zero observations: An extension of the Tobit model. Cahiers Economiques de Brucella's, pp. 379-404.

Blonigen, B.A., Davies, R.B., Naughton, H.T., \& Waddell, G.R. (2005). Spacey parents: Spatial autoregressive patterns in inbound FDI (No. w11466). National Bureau of Economic Research.

Blonigen, B.A., Davies, R.B., Waddell, G.R., \& Naughton, H.T. (2007). FDI in space: Spatial autoregressive relationships in foreign direct investment. European Economic Review, 51(5), $1303-1325$.

Burfisher, M.E., \& Jones, E. (1998). Regional trade agreements \& US agriculture. Agricultural outlook.

Carrere, C. (2006). Revisiting the effects of regional trade agreements on trade flows with proper specification of the gravity model. European Economic Review, 50(2), 223-247.

Condon, N., \& Stern, M. (2011). The effectiveness of African Growth and Opportunity Act (AGOA) in increasing trade from Least Developed Countries. London: EPPI Centre, Social Science Research Unit, Institute of Education, University of London.

Cragg, J. (1971). Some statistical models for limited dependent variables with application to the demand for durable goods. Econometrica, 39, 829-844.

de Vos, A.F., \& Bikker, J.A. (1982). Interdependent multiplicative models for allocation and aggregates: A generalization of gravity models. Vrije Universiteit Amsterdam, Interfaculteit der Actuariële Wetenschappen en Econometrie. 
Denisia, V. (2010). Foreign direct investment theories: An overview of the main FDI theories. European Journal of Interdisciplinary Studies, (3).

Didia, D., Nica, M., \& Yu, G. (2015). The gravity model, African Growth and Opportunity Act (AGOA) and US trade relations with sub-Saharan Africa. The Journal of International Trade \& Economic Development, 24(8), 1130-1151.

Didia, D., Nica, M., \& Yu, G. (2015). The gravity model, African Growth and Opportunity Act (AGOA) and US trade relations with sub-Saharan Africa. The Journal of International Trade \& Economic Development, 24(8), 1130-1151.

Douillet, M. (2012). Trade policy reforms in the new agricultural context: Is regional integration a priority for Sub-Saharan African countries agricultural-led industrialization? Insights from a global computable general equilibrium analysis (No. 1007-2016-79810).

Eaton, J., \& Tamura, A. (1994). Bilateralism and regionalism in Japanese and US trade and direct foreign investment patterns. Journal of the Japanese and International Economies, 8(4), 478-510.

Edwards, S. (1993). Openness, trade liberalization and growth in developing countries. Journal of Economic Literature, 31, 1358-1393.

Eichengreen, B., \& Irwin, D.A. (1998). The role of history in bilateral trade flows. In The regionalization of the world economy (pp. 33-62). University of Chicago Press.

Esmaeili, A., \& Pourebrahim, F. (2011). Assessing trade potential in agricultural sector of Iran: Application of gravity model. Journal of Food Products Marketing, 17(5), 459-469.

Goldberg, L.S. (2009). Exchange rates and foreign direct investment. The Princeton Encyclopedia of the World Economy, 1(1), 393-396.

Grossman, G.M., \& Helpman, E. (1991). Innovation and growth in the global economy. MIT press.

Heckman, J.J. (1979). Sample selection bias as a specification error. Econometrica: Journal of the Econometric Society, pp. 153-161.

Hillberry, R.H. (2002). Aggregation bias, compositional change, and the border effect. Canadian Journal of Economics/Revue Canadienne d'Economique, 35(3), 517-530.

Iloie, R.E. (2015). Connections between FDI, corruption index and country risk assessments in Central and Eastern Europe. Procedia Economics and Finance, 32(1), 626-633.

Linders, G.J., \& De Groot, H.L. (2006). Estimation of the gravity equation in the presence of zero flows. International Journal of Economic Perspectives, 7(3), 57-65.

Marandu, E.E., Mburu, P.T., \& Amanze, D. (2019). An Analysis of Trends in Foreign Direct Investment Inflows to Africa. International Journal of Business Administration, 10(1), 20-32.

Martin, W., \& Pham, C.S. (2015). Estimating the gravity model when zero trade flows are frequent and economically determined. The World Bank.

Nyarko, P.A., Nketiah-Amponsah, E., \& Barnor, C. (2011). Effects of exchange rate regimes on FDI inflows in Ghana. International Journal of Economics and Finance, 3(3), 277-286.

OECD. (2008). OECD Benchmark Definition for Foreign Direct Investment Fourth Edition 2008.

Owusu-Antwi, G. (2012). Determinant of Foreign Direct Investment: Is It a Better Prescription for Economic Growth in Africa? The International Business \& Economics Research Journal (Online), 11(7), 757.

Plümper, T., Schneider, C.J., \& Troeger, V.E. (2006). The politics of EU eastern enlargement: Evidence from a Heckman selection model. British Journal of Political Science, pp. 17-38.

Reinert, K.A. (2006). Gravity models. Princeton Encyclopedia of the World Economy.

Sherif, S. (2013). Intra-Regional Trade, Evidence from the UAE: A Gravity Model Approach.

Tinbergen, J.J. (1962). Shaping the world economy; Suggestions for an international economic policy.

Wang, X., \& Badman, R.P. (2016). A multifaceted panel data gravity model analysis of Peru's foreign trade. arXiv preprint arXiv:1612.01155.

Xia, Y., Houston, J.E., Escalante, C.L., \& Epperson, J.E. (2012). Oilseed trade flows: A gravity model approach to transportation impacts. Journal of Food Distribution Research, 43(856-201658043), 35-42. 
Zenebe, A., Wamisho, K., \& Peterson, E.W.F. (2013). The Impact of the African Growth and Opportunity Act (Agoa): An Empirical Analysis of Sub-Saharan African Agricultural Exports to the United States. Journal of International Agricultural Trade and Development, 9(2), 165.

\section{APPENDIX}

TABLE 1

\section{DESCRIPTIVE STATISTICS OF ESTIMATED AVERAGES}

\begin{tabular}{|l|l|l|l|}
\hline Variables & $\begin{array}{l}\text { Average FDI (Million } \\
\text { US \$) }\end{array}$ & $\begin{array}{l}\text { Average GDP/capita } \\
\text { (Thousand US \$) }\end{array}$ & $\begin{array}{l}\text { Average Political } \\
\text { Stability Index }\end{array}$ \\
\hline West & 648 & 1,000 & 33 \\
\hline East & 567 & 1,700 & 32 \\
\hline Central & 418 & 2,000 & 26 \\
\hline South & 918 & 2,900 & 51 \\
\hline
\end{tabular}

TABLE 2

PROBIT RESULTS

\begin{tabular}{|c|c|c|c|}
\hline Explanatory Variables & Marginal Effect & Coefficient & Standard Errors \\
\hline Per capita GDP & $-0.00^{* * *}$ & $-0.60 * * *$ & 0.00 \\
\hline $\begin{array}{l}\text { Official Exchange } \\
\text { Rate }\end{array}$ & $-0.00 * * *$ & $-0.28 * * *$ & 0.00 \\
\hline $\begin{array}{l}\text { Political Stability } \\
\text { Index }\end{array}$ & $-0.00 *$ & $-0.26^{*}$ & 0.00 \\
\hline Region Name: East & $0.05^{*}$ & 4.64 & 0.02 \\
\hline Region Name: South & -0.06 & -0.51 & 0.05 \\
\hline Region Name: West & 0.00 & 0.05 & 0.02 \\
\hline Language: 1 & -0.03 & -0.35 & 0.02 \\
\hline Language: 2 & -0.04 & -0.48 & 0.03 \\
\hline $\begin{array}{l}\text { Income Classification: } \\
\text { Lower-Middle }\end{array}$ & $0.08 * * *$ & 5.21 & 0.02 \\
\hline $\begin{array}{l}\text { Income Classification: } \\
\text { Upper-Middle }\end{array}$ & $0.08 * * *$ & 5.59 & 0.02 \\
\hline
\end{tabular}

Note: $* * *, * * *$ significant at $10 \%, 5 \%$ and $1 \%$ respectively

\begin{tabular}{|l|l|}
\hline Nobs & 0 \\
\hline Null deviance & 244.36 \\
\hline Df. Null & 622.00 \\
\hline logLik & -92.18 \\
\hline AIC & 206.36 \\
\hline BIC & 255.82 \\
\hline Deviance & 184.36 \\
\hline Df.residual & 652.00 \\
\hline Nobs. 1 & 663.00 \\
\hline
\end{tabular}


TABLE 3

\section{GRAVITY RESULTS}

\begin{tabular}{|l|l|l|}
\hline Explanatory Variables & Coefficients & Standard Errors \\
\hline Per capita GDP & $0.41 * * *$ & 0.08 \\
\hline Official Exchange Rate & -0.00 & 0.04 \\
\hline Other RTAs & -1.56 & 1.29 \\
\hline AGOA Status & $0.97 * * *$ & 0.24 \\
\hline Constant & $16.98 * * *$ & 1.40 \\
\hline
\end{tabular}

Note: $*, * *, * * *$ significant at $10 \%, 5 \%$ and $1 \%$ respectively

\begin{tabular}{|l|l|}
\hline Observations & 663 \\
\hline R2 & 0.10 \\
\hline Adjusted R2 & 0.09 \\
\hline Rho & 0.74 \\
\hline Inverse Mills Ratio & $1.34^{*}(0.69)$ \\
\hline
\end{tabular}

